\title{
Molecular Survey of Theileria annulata in Cattle by PCR - RFLP Method in Iran
}

Jamal Akbari ${ }^{1}$, Javad Javanbakht ${ }^{2 *}$, Moussa Tavassouli ${ }^{3}$, Mohammad Tabatabai ${ }^{4}$ and Rahmehr Shafiei ${ }^{5}$

${ }^{1}$ Graduate Faculty of Veterinary Medicine, Urmia University, Urmia, Iran

${ }^{2}$ Department of Pathology, Faculty of Veterinary Medicine, Tehran University, Tehran, Iran

${ }^{3}$ Department of Parasitology, Faculty of Veterinary Medicine, Urmia University, Urmia, Iran

${ }^{4}$ Department of Microbiology, Faculty of Veterinary Medicine, Shiraz University, Urmia, Iran

${ }^{5}$ Graduate Faculty of Veterinary Medicine, Tehran University, Tehran, Iran

\begin{abstract}
Theileriosis is one of the infectious diseases of cattle and buffalo in tropical countries and Mediterranean region that is of a considerable economical value, generated by Theileria haemoprotozoan and transferred by vetors belonging to Ixodidea. The present study investigates 52 samples in west and east Azerbaijan, Sanandaj and Kermanshah in Iran (2009). In this study, Theileria annulata was separated from ill and healthy cattle by PCR-RFLP method. Especial primers were achieved from Sml-2 gene for this procedure. A fragment of $270 \mathrm{bp}$ was separated from the gathered blood samples. PCR products were distinguished by agarose gel and ultraviolet rays system. Among 22 naturally infected cattle, 13 cases $(59.09 \%)$ were positive in blood smear and $18(81.81 \%)$ were positive in PCR. Among the random sampled healthy cattle, from 30 cases, 4 cases (13.32\%) were positive in blood smear and $5(61.66 \%)$ were positive in PCR. In order to investigate the genetic variation (PCR-RFLP), the separated 270bp fragment was digested by restriction enzymes such as Taql, BSURT, AIUI, Rsal. Taql enzyme generatd (200, 170bp) fragments, AIUI enzyme generated $(120,90,60 \mathrm{bp}) \&(150,90,30 \mathrm{bp})$ fragments and Rsal \& BSURI enzymes could not digest the considered fragment. Finally, six different patterns in genetic variation of relevant gen were observed.
\end{abstract}

Keywords: Gene; Theileriosis; Cattle; PCR; Blood; Enzyme; Base pairs

\section{Introduction}

Theileriosis resulting from Theileria annulata in cattle is an important, dangerous and fatal parasitical disease having great economical value $[1,2,3,4]$. Theileria spp infects domestic and wild ruminants in tropical and subtropical regions in the world [5]. Also, it is a piroplasma protozoa of cattle and buffalo called tropical fever made by a kind of Theileria such as annulata [3].And causes Lympho-proliferation disease, which is a high rate mortality disease [6]. Theileria annulata infects lineage cells of macrophage/monocytes and B Lymphocytes in cattle $[7,8]$. According to the evaluations, more than 200-250 million cattle and calf are at the risk of theileriosis all around the world [9]. Some important clinical signs of this disease are inflation of prescapular and prefemoral lymphatic glands, fever, diarrhea, anorexia, anemia of eye \& vagina mucus, jaundice and outpouring of nose water [9-13]. Theileria annulata is one of the fatal Theiloriosis in Europe, North Africa and Middle East [14]. In a study on 680 ticks taken from 107 infected cattle by Theileria annulata, the results were as follows: $92 / 35 \%$ (Hyalomma anatolicum anatolicum), 5/14\% (Hyalomma anatolicum excevatum), $1 / 17 \%$ (excevatum excevatum), 1/32\% (Rhipicephalus Sang) $[3,12,15]$. Theileria annulata does most of the cattle infection by ticks in Iran causing the death of domestic animals. The first report was announced in 1935 transferred by Hyalomma excevatum and $H$. Detritum [3,15,16]. The researchers observed infected materials called "Koch blue body" in lymphatic glands, liver and spleen of affected cattle that is the schizont stage of parasites. In north part of Iran, especially in North West and some parts of the west where the activity season is short due to having long winters [3]. Several studies and reports of this parasite are available. The first study was done by Rachel Adamson et al. [17] titled "Transient transfection of Theileria annulata". The second one has been done by Schinittger et al. [5] named "sequence analysis of Theileria Lestoquardi and a Theileria species highly pathogenic for small ruminants in China. Heidarpour Bami et al. [18] research was Molecular identification of ovine Theileria species by a new PCR-PFLP method. In 2008, Kursat Altay et al. [19] conducted a study named molecular detection of Theileria and Bebsia infections in cattle. Distinction accomplishes in regard to season, background and clinical signs. But the exact distinction of this organism is necessary for its classification and epidemiology. At first, the existence of Theileria would be definite by preparing blood smear and aspiration from inflated lymphatic gland and observing parasite in RBC or schizont $[15,17]$. Serological test, indirect immunofluorescent test and also the carriers would be distinguished by PCR $[19,20]$. Several successful studies and reports of cattle's PCR have been done [1,21-23].This molecular technique reveals a high sensitivity compared to monological examination and serological testing [24]. The progress in molecular biology can prove genotopic and useful characteristics for recognition and classification of numerous kinds of homoparasite from Theileria group [25]. By PCR, Theileria can be identified from Anaplasmasis [26], Babesiosis [27], Leptospirosis [3], Leucosis [28] and brain form of theileria [12]. PCR is a revolutionary method developed by Kary Mullis in 1980 [15,24]. Polymerase Chain Reaction (PCR) is a biological and molecular technique for DNA enzymatic transcription without using live organism such as E. coli and usually is used for medical and biological investigations for different purposes. PCR is used for small fragment duplication of DNA string and it can be a single gene or part of a gene [29]. PCR process has 3 phases, which includes 20-35 cycles, and each cycle has three parts

*Corresponding author: Javad javanbakht, Department of Pathology, Faculty of Veterinary Medicine, Tehran University, Tehran, Iran, Tel:+989372512581; E-mail: javadpatho@yahoo.com

Received January 02, 2012; Accepted March 26, 2012; Published April 1, 2012

Citation: Akbari J, Javanbakht J, Tavassouli M, Tabatabai M, Shafiei R (2012) Molecular Survey of Theileria annulata in Cattle by PCR - RFLP Method in Iran. Bacteriol Parasitol 3:135. doi:10.4172/2155-9597.1000135

Copyright: (C) 2012 Akbari J, et al. This is an open-access article distributed unde the terms of the Creative Commons Attribution License, which permits unrestricted use, distribution, and reproduction in any medium, provided the original author and source are credited. 
[24,30]. The present study investigates molecular survey of Theileria annulata in cattle by PCR_RFLP method.

\section{Matherials and Method}

\section{Field study area}

The study was conducted on 52 cattle in the provinces of west Azerbaijan, East Azerbaijan, Kermanshah and Sanandaj located in the North West of Iran (2011) (Figure 1). This area has varying weather conditions. Unlike the dry and hot East and Central Iran regions, a climate region with rainfall and mild temperatures with warmer summers and colder winters.

\section{Experimental approach}

In 2011, during a period corresponding to the season of tick activity, every cattle suspected to Theileriosis was clinically examined. Then, blood smears were prepared from jugular vein. Also, the whole body of animal was inspected for the presence of ticks; the ticks removed were put into labelled flasks. They were kept cool and humid during return to the laboratory for further identification and examination

\section{Collection of blood samples, blood smears and microscopic examination}

Blood samples (stored at $20^{\circ} \mathrm{C}$ until DNA extraction and gathered randomly. The age of animals ranged between 5-6 months and 12 years old, and all were clinically healthy (None of the cattle had received treatment or a vaccination to block theileriosis.) were collected (The procedure of gathering samples took three continuous months) in EDTA from cattle exposed to Ixodid ticks in four geographical areas in Iran. Blood (All blood samples were collected from a jugular vein into anticoagulant EDTA bottle, about $5 \mathrm{ml}$ bloods was taken from jugular vein of cattle) was used to prepare thin blood smears for microscopic examination and to extract DNA for PCR analysis. Then transferred to Alsiver environment the sample was immediately put into refrigerator. Blood smears were air-dried, fixed with methanol for five min, stained in $10 \%$ Giemsa at a dilution of $5 \%$ in buffer solution for $30 \mathrm{~min}$, and

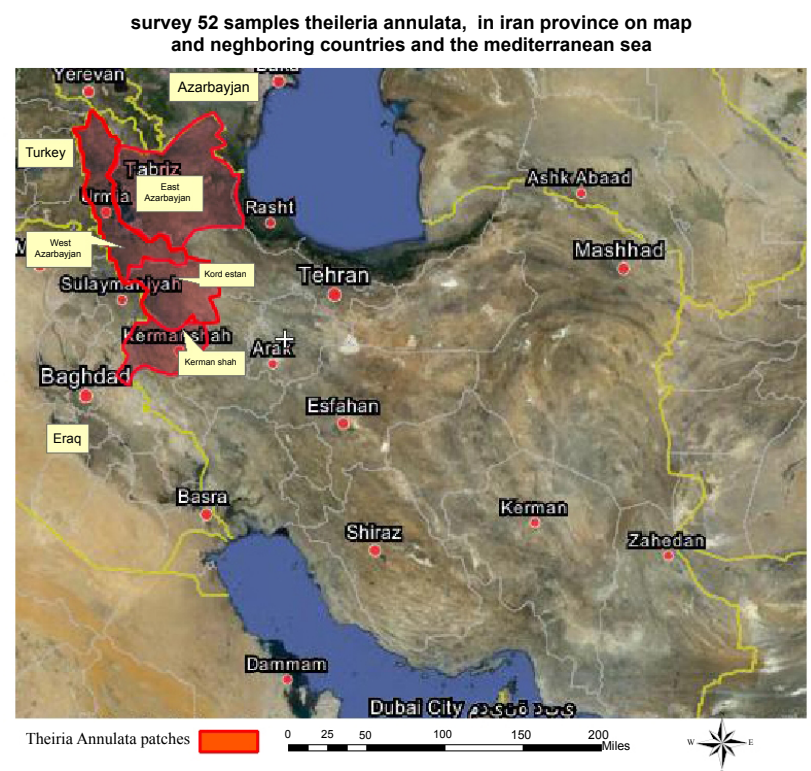

Figure 1: Surveying of 52 samples of Theileria annulata in iran provinceon map and neighboring countries and the Mediterranean sea. then examined for the presence of Theileria annuluta under light microscopy.

\section{DNA extraction}

DNA extraction was performed as described by Lennette method. Briefly, $200 \mathrm{ml}$ of blood was added to $500 \mathrm{ml}$ of lysis solution $(0.32 \mathrm{Msu}-$ crose, $0.01 \mathrm{MTris}, 0.005 \mathrm{M} \mathrm{MgCl}, 1 \%$ Triton X-100, and $\mathrm{pH}$ 7.5). The mixture was centrifuged at $13000 \times \mathrm{g}$ for $5 \mathrm{~min}$. The pellet was washed three times by centrifugation with $500 \mathrm{ml}$ lysis buffer. The final pellets were resuspended in $100 \mathrm{ml}$ of PCR buffer $(50 \mathrm{mM} \mathrm{KCl}, 10 \mathrm{mM}$ Tris$\mathrm{HCl}$ and $\mathrm{pH}$ 8.3), 0.1\% Triton X-100, $\mathrm{pH} 8.3)$. Proteinase $\mathrm{K}(50 \mathrm{mg} / \mathrm{ml})$ was added to the pellet suspension, and the mixture was incubated at $56.8^{\circ} \mathrm{C}$ for $1 \mathrm{~h}$. Finally, the samples were heated at $100.8^{\circ} \mathrm{C}$ for $10 \mathrm{~min}$.

\section{Primers designed and PCR}

For PCR amplification of Theileria annulata: One set of primers was used to amplify an approximately 270bp fragment of the Sml-2. Outer primersfor the primary PCR were forward strand primer Thei F1:5'_TGT-CAA-GGA-GGC-CTC-AAA-TT-3' and reverse strand primer Their F21:5'_TTT-GAC-TTT-GAA-TAG-GGT-GC-3'

Were used as described by Schnittger et al. [5]. For differentiation of various Theileria restriction fragment length polymorphism (RFLP) of PCR products of the Sml-2 of Theileria annulata was done. The PCR amplified a monomorphic DNA fragment of 270 bp (Fermentas, Germany) which was sequenced and analyzed for the presence of restriction sites that differentiated the one haemoprotozoan in the presence of the host DNA. The enzymes TaqI, BSURT, AIUI and RsaI. TaqI were used. The amplified products were digested with restriction enzymes (Fermentas) as described by the supplier, and analyzed by agarose gel electrophoresis on a $2 \%$ gel. The digestion reaction was set up in $20 \mu \mathrm{l}$ volumes in $500 \mu \mathrm{l}$ PCR tubes. $10 \mu \mathrm{l}$ of the PCR product was used for each digestion. The digestion mixture consisted of $2 \mu$ l of the $10 \times$ buffer, $10 \mu l$ PCR product and $1 \mu \mathrm{l}(10 \mathrm{U})$ of the restriction enzyme made up to $20 \mu \mathrm{l}$ with autoclaved triple-distilled water. The digestion mix was incubated at $37^{\circ} \mathrm{C}$ for $2 \mathrm{~h}$. The restriction enzyme analysis of the PCR-amplified DNA fragments was performed by electrophoresis on the ethidium bromide-stained $2 \%$ agarose gel. .the gel; we cut off the electricity and transfer the gel to the UV transaulv mynatur to be observed. While working with Ethidium bromide we must use gloves and mask and after observing the gel in UV, and transfer the gel to the dangerous garbage section.

\section{Restriction digestion}

Twenty microlitres of amplified DNA from the PCR reaction were subjected to restriction enzymes digestion using TaqI, BSURT, AIUI, and RsaI. According to manufacturer's instructions (Promega, USA) and visualised by agarose gel electrophoresis (Table 1).

\section{Results}

Among 52 blood samples, 19 cases of them were from west Azerbaijan, 3cases from veterinary clinic of Tabriz University having some clinical signs and 30 cases were randomly chosen from Sanandaj and Kermanshah from healthy and suspicious cattle. The result of the blood smear is as below: 1) West Azerbaijan and clinic: 13 positive cases and 9 negative cases. 2) Sanandaj and Kermanshah: 4 positive cases and 26 negative cases. Positive numbers of west Azerbaijan and clinic: (1, 2, $4,7,8,9,10,11,13,14,17,18,19)$, Positive numbers of Sanandaj and Kermanshah: $(1,12,5,52)$ (Figure 2 and 3 ). 
Citation: Akbari J, Javanbakht J, Tavassouli M, Tabatabai M, Shafiei R (2012) Molecular Survey of Theileria annulata in Cattle by PCR - RFLP Method in Iran. J Bacteriol Parasitol 3:135. doi:10.4172/2155-9597.1000135

Page 3 of 6

\begin{tabular}{|c|c|c|c|c|}
\hline Enzyme & Cut & Buffer & Thermal Digestion & Inactivation \\
\hline Taql & $\begin{array}{l}5^{\prime} \ldots \text { TGGA } \ldots . \text { 3' } \\
\text { 3' ... AGCT ... 5' }\end{array}$ & Unique & $65^{\circ} \mathrm{C}$ & $2 / 0 \mathrm{~L}$ of EDTA $0 / 5 \mathrm{M}$ \\
\hline BSURI & $\begin{array}{l}5^{\prime}, \ldots \text { GCCC } \ldots .3^{\prime} \\
3^{\prime} \ldots \text { CCCG } \ldots .55^{\prime}\end{array}$ & $\mathrm{R}$ & $37^{\circ} \mathrm{C}$ & $80^{\circ} \mathrm{C}$ for $20 \mathrm{~min}$ \\
\hline RSal & $\begin{array}{l}5^{\prime}, \ldots \text { GTAC } \ldots \text { 3' } \\
3^{\prime}, \ldots \text { CATG } \ldots \text { 5' }\end{array}$ & Tango & $37^{\circ} \mathrm{C}$ & $65^{\circ} \mathrm{C}$ for $20 \mathrm{~min}$ \\
\hline Alul & $\begin{array}{l}5^{\prime} \ldots \text { AGCT } \ldots \text { 3' } \\
\text { 3' ... TCGA . . . 5' }\end{array}$ & Tango & $37^{\circ} \mathrm{C}$ & $65^{\circ} \mathrm{C}$ for $20 \mathrm{~min}$ \\
\hline
\end{tabular}

Table 1: Twenty microlitres of amplified DNA from the PCR reaction were subjected to restriction enzymes digestion using TaqI, BSURT, AIUI, and Rsal. According to manufacturer's instructions (Promega, USA) and visualised by agarose gel electrophoresis.

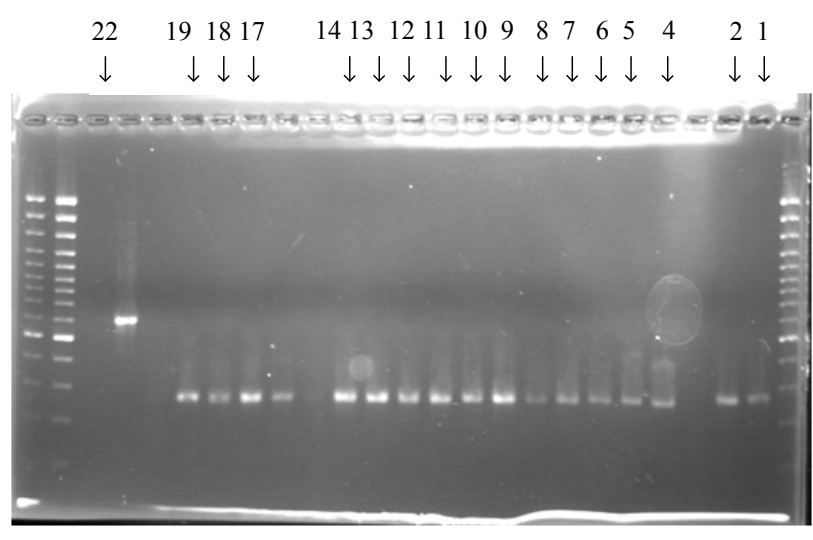

Figure 2: Positive samples of West Azerbaijan and clinic, Sample 22 is positive control and the first and last two ones are marker $100 \mathrm{bp}$, Voltage is $150 \mathrm{~V}$, gel density is $1 \%$ and running time is $1 / 35$ hours.

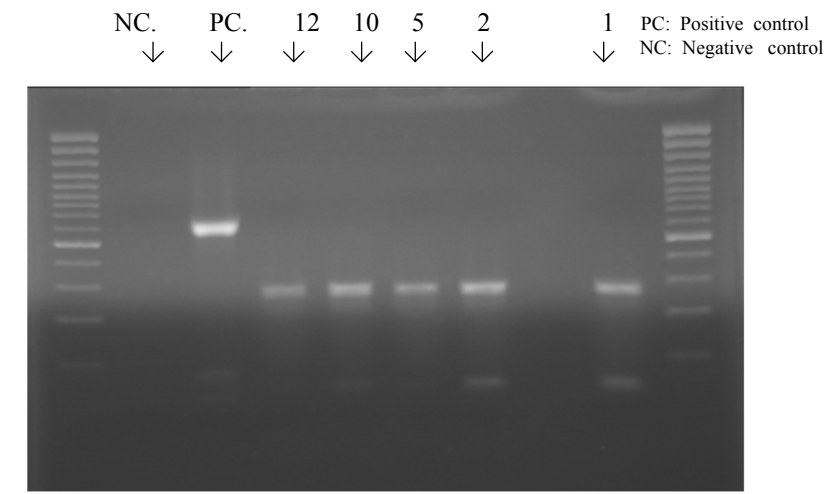

Figure 3: Positive samples from Sanandaj and Kermanshah, the first and the last marker $100 \mathrm{bp}$

\section{The result of PCR on blood samples}

By doing PCR on blood samples of west Azerbaijan and clinic, among 22 of collected samples from 12 age cattle and 5-6 months calf which had clinical signs of Theileriosis, 18 cases were positive and the size of separated fragment was $270 \mathrm{bp}(22,16,1,2,4,5,6,7,8,9,10$, $11,12,13,14,19,17,18)$. While there were only 5 positive cases in Sanandaj and Kermanshah $(1,2,5,10,12)$. Also, in this case, the size of separated fragment was $270 \mathrm{bp}$. (Table 2,3 and 4) The results of genetic diversity of Theileriosis annulata samples by enzymatic digestion of PCR products (RFLP-PCR) and positive samples of PCR products by using TaqI, BSURI, and AIUI enzymes were examined and the results were as follow:

\begin{tabular}{|c|c|c|}
\hline Sample no. & smear & PCR \\
\hline 1 & + & + \\
\hline 2 & + & + \\
\hline 3 & - & - \\
\hline 4 & + & + \\
\hline 5 & - & + \\
\hline 6 & - & + \\
\hline 7 & + & + \\
\hline 8 & + & + \\
\hline 9 & + & + \\
\hline 10 & + & + \\
\hline 11 & + & + \\
\hline 12 & - & + \\
\hline 13 & + & + \\
\hline 14 & + & + \\
\hline 15 & - & + \\
\hline 16 & - & + \\
\hline 17 & + & + \\
\hline 18 & + & + \\
\hline 19 & + & + \\
\hline 20 & - & - \\
\hline 21 & - & - \\
\hline 22 & - & + \\
\hline
\end{tabular}

Table 2: The results of samples gathered from Kermanshah \& Sanandaj.

\begin{tabular}{|c|c|c|}
\hline Sample no. & smear & PCR \\
\hline $1 \mathrm{~A}$ & - & - \\
\hline $2 \mathrm{~A}$ & + & - \\
\hline $3 \mathrm{~A}$ & - & - \\
\hline $4 \mathrm{~A}$ & - & + \\
\hline $5 \mathrm{~A}$ & - & - \\
\hline $6 \mathrm{~A}$ & - & - \\
\hline $7 \mathrm{~A}$ & - & - \\
\hline $8 \mathrm{~A}$ & - & - \\
\hline $9 \mathrm{~A}$ & - & + \\
\hline $10 \mathrm{~A}$ & + & - \\
\hline $11 \mathrm{~A}$ & & + \\
\hline $12 \mathrm{~A}$ & + & - \\
\hline & - & - \\
\hline $30 \mathrm{~A}$ & - & \\
\hline
\end{tabular}

Table 3: The results of samples gathered from East \& West Azerbaijan.

\begin{tabular}{|c|l|l|c|c|c|c|}
\hline & \multicolumn{1}{|c|}{ Province } & $\mathbf{n}$ & & + & $\%$ \\
\hline Blood smear Test T & With clinical signs & $\begin{array}{l}\text { East \& West } \\
\text { Azerbaijan }\end{array}$ & 22 & 9 & 13 & $59 / 09 \%$ \\
\hline & $\begin{array}{l}\text { Without clinical } \\
\text { signs }\end{array}$ & $\begin{array}{l}\text { Sanandaj \& } \\
\text { Kermanshah }\end{array}$ & 30 & 26 & 4 & $13 / 33 \%$ \\
\hline $\begin{array}{l}\text { Total statistics of 52 } \\
\text { samples in blood } \\
\text { smear }\end{array}$ & $\begin{array}{l}\text { With clinical signs \& } \\
\text { without clinical signs }\end{array}$ & All provinces & 52 & 35 & 17 & $32 / 69 \%$ \\
\hline $\mathrm{n}$ & Number of samples \\
\hline+ & Positive samples \\
\hline- & Negative samples & & \\
\hline
\end{tabular}

Table 4: Investigating the results of blood smear and PCR in samples from neighboring provinces of Turkey, Iraq \& Azerbaijan Republic in Iran.

A) The results of digestion by TaqI enzyme: From 23 positive case, 11 of them were not digested (270bp), 3 cases were $70 \& 200$ and 9 cases were 100, 170. This shows two different places for TaqI enzyme in Theileria annulata DNA (Table 5 and Figure 4).

B) Digestion results of BSURI enzyme: No sample was digested among 23 samples (Figure 5). 
Citation: Akbari J, Javanbakht J, Tavassouli M, Tabatabai M, Shafiei R (2012) Molecular Survey of Theileria annulata in Cattle by PCR - RFLP Method in Iran. J Bacteriol Parasitol 3:135. doi:10.4172/2155-9597.1000135

Page 4 of 6

\begin{tabular}{|c|c|c|c|}
\hline Sample No. & Digestion with/by Taql & Sample No. & Digestion with/by Taql \\
\hline 1 & 100,170 & 13 & 170,100 \\
\hline 2 & 200,70 & 14 & 170,100 \\
\hline 4 & 200,70 & 16 & 170,100 \\
\hline 5 & 200,70 & 17 & 270 \\
\hline 6 & 270 & 18 & 270 \\
\hline 7 & 170,100 & 19 & 270 \\
\hline 22 & 270 & & \\
\hline 8 & 270 & A1 & 270 \\
\hline 9 & 170,100 & A2 & 270 \\
\hline 10 & 170,100 & A5 & 270 \\
\hline 11 & 170,100 & A10 & 270 \\
\hline 12 & 170,100 & A12 & 270 \\
\hline
\end{tabular}

Table 5: Digestion results by Taql (samples 1 to 22 are related to west Azerbaijan \& clinic and samples $\mathrm{A} 1$ to $\mathrm{A} 12$ are related to Sanandaj \& Kermanshah.

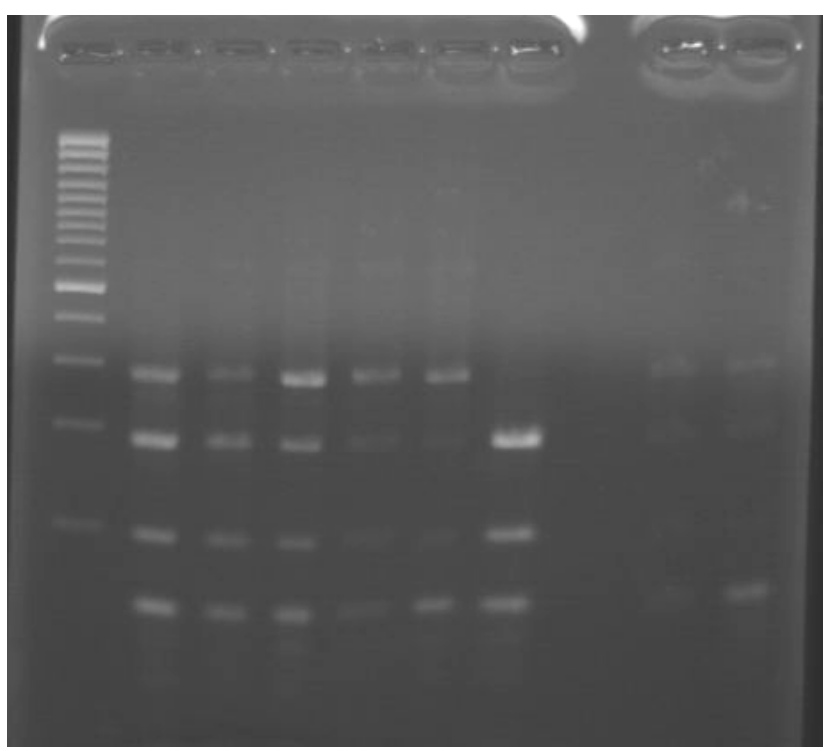

Figure 4: Enzymatic digestion by Taq 1.

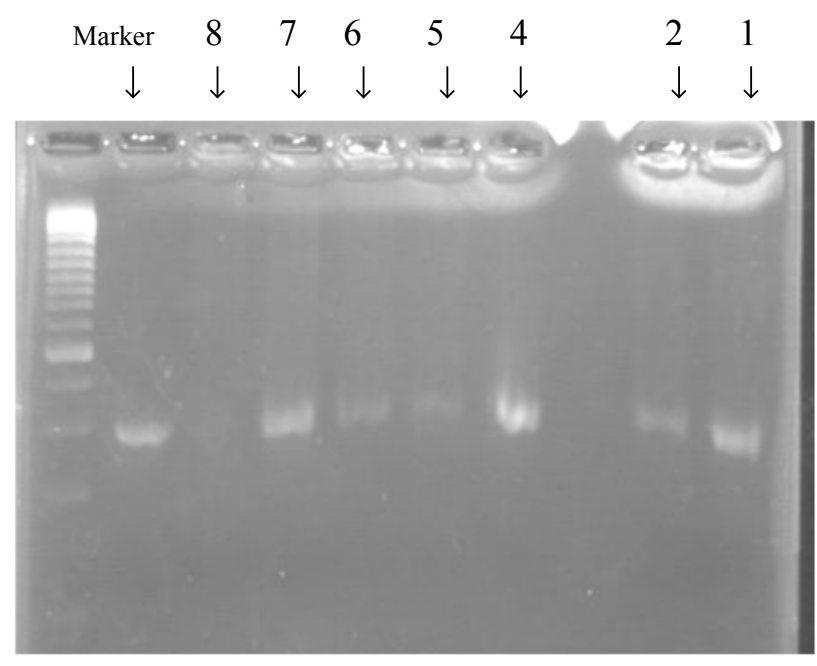

Figure 5: Samples not digested by BSURI enzyme.
C) The results of digestion by RsaI: Among 83 positive samples, none of them were digested by RsaI.D) the results of digestion by AIUI: among 23 positive samples, 7 cases $(270 \mathrm{bp})$ didn't digest, 14 cases were $(60,90,120)$ and 2 cases were $(30,90,150)$. This shows two different places for AIUI enzyme in Theileria annulata DNA (Table 6).

\section{Abstract of PCR results}

By doing PCR on blood samples the following results were obtained.

(a) We could separate Theileria annulata (270bp) by doing PCR with special primers.

(b) In blood smear of cattle having clinical signs of Theileriosis, 13 cases were positive out of $22(59 / 09 \%)$.

(c) In PCR, 18 cases were positive among 22 cases (81/18\%).

(d) In blood smear of cattle having no clinical signs, 4 cases were positive among 30 (13/33\%).

(e) In PCR, 5 cases were positive among 30 cases without having any clinical sign $(66 / 16 \%)$

(f) Totally, among 52 healthy and ill cattle, 17 cases were positive in blood smear $(32 / 69 \%)$

(g) Among 52 cases, 23 cases were positive in PCR (44/23\%).

\section{Marker AluI RsaI BsuRI TaqI TaqI}

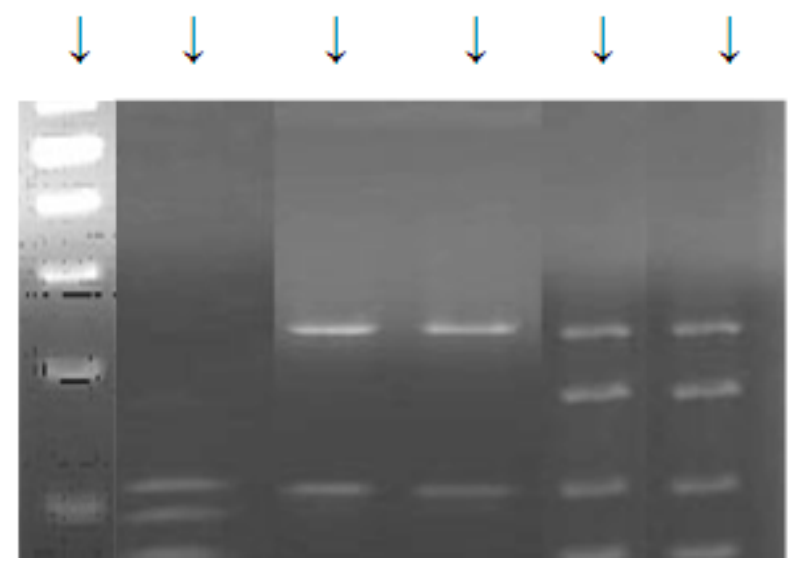

Figure 6: The results of enzymatic digestion by Taq $1(170,100)$, BSURI (270), Rsal (270) and AIUI $(60,90,120)$ enzymes.

\begin{tabular}{|l|l|l|l|}
\hline Sample No. & Digestion by AIUI & Sample No. & Digestion by AIUI \\
\hline 1 & $120,90,60$ & 13 & $120,90,60$ \\
\hline 2 & 270 & 14 & $150,90,30$ \\
\hline 4 & 270 & 16 & $120,90,60$ \\
\hline 5 & 270 & 17 & $120,90,60$ \\
\hline 6 & 270 & 18 & $120,90,60$ \\
\hline 7 & 270 & 19 & $120,90,60$ \\
\hline 22 & & & \\
\hline 8 & $120,90,60$ & A1 & \\
\hline 9 & $120,90,60$ & A2 & $120,90,60$ \\
\hline 10 & $120,90,60$ & A5 & \\
\hline 11 & $120,90,60$ & A10 & \\
\hline 12 & $120,90,60$ & A12 & 170,100 \\
\hline
\end{tabular}

Table 6: Digestion results by AIUI. 
An abstract on the results of surveying genetic variation with enzymatic digestion. By using four DNA digesting enzymes, 6 different patterns were diagnosed in genetic variation of SmI-2 of Theileria annulata.

\section{Discussion}

Theileriosis is an important and dangerous parasitical disease resulted from Theileria annulata and transferred by different kinds of ticks belonging to Hyalomma. This disease is seasonal, starts in the second part of April, adds to its abundance gradually and this abundance increases in June and July but in August and September the number of affected cattle is reduced by temperature decreasing and ticks' activity [32]. According to the estimates, about 200 million cattle and calf are at the risk of Theileriosis resulting from Theileria annulata and about 9 million of them are perished annually [9]. According to Christine study Theileria annulata is a protozoan parasite of domestic cattle and buffalo (Babalus Babalus) transferred by Hyalomma ticks. This disease is spread in North Africa, South Europe, India, South Russia and Middle East and contains $90 \%$ death rate in non-aboriginal races, and $\% 5$ and less in aboriginal races [32]. Cattle with subclinical Theileriosis become chronic carrier of the piroplasm and, hence, sources of infection for tick vectors. Therefore, latent infections are important in the epidemiology of the diseases. The diagnoses of piroplasm infections are based on clinical findings and microscopic examination of Giemsa-stained blood smears [22]. In this period, erythrocytes infected by piroplasma Theileria annulata. In this situation, finding Theileria annulata in blood smear is very difficult. On the other hand, under field condition, the diagnosis of Theileriosis resulting from Theileria annulata or Theileria mutans that have low pathogenetic is important and it is impossible to distinguish Theileria annulata from other kinds of Theileria [32]. By the invention of PCR method, sensitivity diagnosis test has improved [32]. According to the study done on Theileria annulata by PCR method using special primers of main antigen of the surface of merzoite Theileria annulata $(30-\mathrm{kDa})$, the specialty of the procedure in non-duplicating DNA of the theileriosis except Theileria annulata (such as Theileria pavra, Theileria mutans and Theileria Sergenti) and other blood parasites (such as anaplasma marginale, anaplasma centrale, Babesia bovis and Bayjimna) was confirmed. In this investigation, from 52 samples, $32 \%$ of them were positive in blood smear, $40 \%$ in IFA and $75 \%$ in PCR. This shows that PCR is a useful instrument for Theileria strain isolation with high security [32]. Another study investigates the prevalence of Theileria sergenti in aboriginal cattle by PCR method with a private primer, the $128 \mathrm{bp}$ fragment was reproduced. In this study, 300 cattle were investigated that $\% 8$ of them were positive in blood smear. Meanwhile, $67.8 \%$ was positive in PCR method. In addition, this study indicated that the amount of infection in female cows were $70.3 \%$ and $40 \%$ in males ( $\mathrm{p}<0 / 01)$ and also the amount of Theileria sergenti in cattle older than 3 years old were $75 \%$ and $61.8 \%$ in cattle younger than 3 years $(p<0 / 05)$. In this study, the amount of infection in pasture cattle was $\% 71.6$ and $\% 51$ in non-pasture cattle $(\mathrm{p}<0 / 01)$ [33]. In a research by Witkowski et al. [29] on Theileria carrier ticks in infected cattle by PCR and probe DNA, it was indicated that $56 \%$ of the ticks out of a hundred feeding from infected animals were positive in PCR method. Meanwhile in probe DNA 37\% of them (ticks) were positive and in the ticks on carrier cattle, $28 \%$ of them were positive in PCR method and $1.33 \%$ were positive in probe DNA [29]. In a study on apparently healthy and afflicted cattle by PCR method using special primers (Sml_2), it was distinguished that Theileria annulata is dominant strains of Theileria in west Azerbaijan. In this investigation, among 22 infected cattle by Theileria annulata that were ill naturally,
$59.09 \%$ of them were positive in blood smear and $81.81 \%$ were positive in PCR and from 30 healthy cattle in blood smear which was difficult to distinguish, 3.33\% of cases were positive in blood smear and $16.66 \%$ were positive in PCR. This study is matched to Kristine et al. study \& Kun-Ho Song and shows that PCR is a powerful instrument for Theileria annulata with high sensitivity and specialty and non of the previous methods are comparable to PCR method. Because of high specialty and sensitivity of PCR method, Tilhan et al. [31] did a study on the effect of Sialic acid in resistance infection. For the purpose of this study, they infected 16 cattle tentatively with Theileria annulata their infection was confirmed by PCR method, and 13 cattle were selected by PCR as a negative control. The density of Sialic acid in control cattle was $1141 / 38 \pm 68 / 14 \mu \mathrm{g} / \mathrm{ml}$ and was $252 / 09 \pm 47 / 95 \mu \mathrm{g} / \mathrm{m}(\mathrm{p}<0 / 01)$ in infected cattle. It was $1502 / 71 \pm 116 / 13 \mu \mathrm{g} / \mathrm{m}(\mathrm{p}<0 / 05) 3$ months after the treatment in infected cattle that was higher than the control cattle. This showed that Theileria annulata increases Sialic acid and is indirectly effective in setting up and sustaining infection in hosts' body [34]. We can identify Eimeria in picogram (less than 10 oocytes) by PCR. Cryptosporidium is recognized in excrement by microscope when the number of oocyte is more than 50000 in excrement, While, Cryptosporidium parum is recognizable by 16 oocyte in PCR method [35]. PCR have many problems by its unique characteristics. Some of them are the high cost compared to the smear staining, the need to train experts and have special abilities for recognition [36]. Also, PCR is not able to recognize dead parasites from the alive. Furthermore, it may seem false positive because of the high sensitivity and unwanted DNA infection. Now, PCR is semi-quantity and vague test and is completely substituted instead of old recognition procedures in developed countries [37]. In genetic variation with restriction enzymes on $270 \mathrm{bp}$ fragment for Theileria annulata genome, the considered fragment was digested by restriction enzymes of RsaI, TaqI, BSURI \& AluI. TaqI enzyme generated fragments (170,100bp), (200,70bp), AluI enzyme generated fragments $(60,90,120 \mathrm{bp})$ and fragment $(30,90,150)$, RsaI \& BSUR enzymes were not able to digest any of the samples. In total, 52 samples were studied in Theileria annulata genome and 6 different PCR-RFLP patterns were observed. Due to the high sensitivity and specialty of PCR, this method can be used to check the carriers in large herds to eradicate the disease. In the case of having educated and sophisticated human resource, this method can be used in high-inflected regions instead of blood smear. However, sporadic cases are not affordable due to high cost.

\section{References}

1. M'ghirbi Y, Hurtado A, Barandika JF, Khlif K, Ketata Z, et al.(2008) A molecular survey of Theileria and Bebesia parasite in cattle with a note on the distribution of ticks in Tunisia. Parasitol Res 103: 435-442.

2. Gardiner P, Devendra C (1995) Global Agenda for Livestock Research. Nairobi ILRI 41-80.

3. Hashemi FR (1988) Cattle Theileriosis in Iran. Agricultural Research Organization $30-84$.

4. Robinson PM (1982) Theileria annulata and its transmission - a review. Trop Anim Health Prod 14: 3-12.

5. Schnittger L, Yin H, Jianxun L, Ludwig W, Shayan P, et al. (2000) Ribosomal small- subunit RNA gene sequence analysis of Theileria Lestoquardi and a Theileria species highly pathogenic for small ruminants in China. Parasitol Res 86: 352-358.

6. Allsopp BA, Baylis HA, Allsopp MT, Cavalier-Smith T, Bishop RP, et al. (1993) Discrimination between six species of Theileria using Oligonucleotide probes which detects small subunit ribosome RNA sequence. Parasitol 107: 157-165.

7. Uilenberg G (1995) International collaborative research: significance of tickborne hemoparasitic disease to world animal health. Vet Parasitol 57: 19-41. 
Citation: Akbari J, Javanbakht J, Tavassouli M, Tabatabai M, Shafiei R (2012) Molecular Survey of Theileria annulata in Cattle by PCR - RFLP Method in Iran. J Bacteriol Parasitol 3:135. doi:10.4172/2155-9597.1000135

8. Campbell JD, Brown DJ, Glass EJ, Hall FR, Spooner RL (1994) Theileria annulata sporozite targets. Parasite Immunol 16: 501-505

9. Sager H, Bertoni G, Jungi TW (1998) Different Ces between B cell and Macrophage transformation by the bovine parasite Theileria annulata: a clonal approach. J Immunol 161: 335-341.

10. Shirazi J (1992) Investigating clinical materials of Theileriosis in ruminants' Urmia Veterinary Medicine Faculty, Iran.

11. Rafiei A (1990) Investigating clinical materials of Theileriosis in ruminants. Urmia Veterinary Medicine Faculty, Iran

12. Sileghem M, Flynn JN, Logan-Henfrey L, Ellis J (1994) Tumor necrosis factor production by monocytes from cattle infected with Typanosoma (Duttonella) vivax and Trypanosoma (Nannomonas) congolense possible association with severity of anaemia associated with disease. Parasite Immunol 16: 51-54.

13. Hirunpetcharat C, Finkelman F, Clark IA, Good MF (1999) Malaria parasitespecific Th1- like $T$ cells simultaneously reduces parasitaemia and promotes disease. Parasite Immunol 21: 319- 329

14. Irvin AD, Morrison WI (1997) Immune pathology and immuno prophglaxis of Theileria infection immune response. Parasitic Infection 223-270.

15. Vilenberg G (1981) Theileria species of domestic Livestock. Martinus Nijhoff The Hague.

16. Hashemi FR (1986) Theiloriosis due to the Theileria annulata in Iran. Tehran

17. Altay K, Dumanli N, Aktas M (2007) molecular identification, genetic diversity and distribution of Theileria and babesia species infecting small ruminants. Vet Parasitolo 147: 161-165.

18. Heidarpour BM, Haddadzadeh HR, Kazemi B, Khazraiinia P, Bandehpour M et al. (2009) Molecular identification of ovine Theileria species by a new PCRRFLP method Vet Patholo 161: 171-177.

19. Altay K, Aydin MF, Dumanli N, Aktas M (2008) Molecular detection of Theileria and Bebesia infections in cattle. Vet Parasitol 158: 295-301.

20. Burridge MJ, Brown CG, Kimber CD (1974) Theileria anulata: cross-reactions between a cell culture schizont antigen and antigens of East Africans species in the indirect fluorescent antibody test. Exp Parasitol 35: 374-380

21. Leemans I, Brown D, Hooshmand-Rad P, Kirvar E, Uggla A (1999) Infectivity and cross-Immunity studies of Theileria Lestoquard and Theileria annulata in sheep and cattle: I. Invivo responses. Vet Parasitol 82: 179-192.

22. Aktaş M, Altay K, Dumanli N (2005) Development of a polymerase chain reaction method for diagnosis of Babesia ovis infection in sheep and goats. Vet Parasitol 133: 277-281.
23. García-Sanmartín J, Nagore D, García-Pérez AL, Juste RA, Hurtado A (2006) Molecular diagnosis of Theileria and Bebesia species infecting cattle in Northern Spain using reverse Line blot Macroarrays. BMC Vet Res 2:16.

24. Shah D, Mohammad H, Mehrani S (1990) Polymers cycle reaction. 113-118.

25. Papadopoulos B, Brossard M, Perié NM (1998) Piroplasms of domestic animals in the macedonia region of Greece. 3. Prioplasms of small ruminants. Vet Parasitol 63: 67-74.

26. Cacciò S, Cammà C, Onuma M, Severini C (2000) The beta-tubulin gene of Bebesia and Theileria parasites is an informative marker for species discrimination. Int J Parasitol 30: 1181-1185.

27. Hofmann-Lehmann R, Meli ML, Dreher UM, Gönczi E, Deplazes P, et al. (2004 Concurrent infections with vector-borne pathogens associated with fatal homolytic anemia in a cattle herd in Switzerland. J Clin Microbiol 42: 3775-3780.

28. Radositis OM, Gay DC, Blood KW, Hinch, C (2000) Veterinary medicine. A textbook of the disease of cattle, sheep, pigs, goats and horses. (9thedn), W B Saunders co, LTD. London, UK.

29. Smith and Beraford (1996) Internal medicine in big herds. Nourbakhsh publication.

30. Witkowski J, Zoller M, Watson JD (1992) Recombinant DNA (2ndedn).

31. Ilhan KT, Kargin FK, Seyrek K, Bildk A, Eren H (2005) Detection of serum total sialic acid in cattle with natural tropical Theileriosis. Revue Med Vet 156: 578582.

32. Assadpour A, Rahimabadi Y (1990) Investigating clinical materials of Theile riosis and its frequency rate in Urmia. Urmia Veterinary Medicine Faculty, Iran.

33. d'Oliveira C, van der Weide M, Habela MA, Jacquiet $P$, Jongejan F (1995) Detection of Theileria annulata in Blood Samples of Carrier Cattle by PCR. J Clin Microbiol 33: 2665-2669.

34. Song KH, Sang BC (2003) Prevalence of Theileria sergenti infection in Korean native cattle by Polymerase Chain Reaction. Korean J Parasitol 41: 141-145.

35. Pain A, Renauld H, Berriman M, Murphy L, Yeats CA, et al. (2005) Genome of the host-cell transforming parasite Theileria annulata compared with T. Parva. Science 309: 131-133.

36. Dolan TT (1989) Theiloriosis a comprehensive review of fice International des Epizoeties. Vet Parasitol 8: 11-36.

37. Sam B, Russel DW (2001) Molecular cloning a laboratory manual. (3rdedn) cold spring Harbor laboratory press. New York. 